\title{
Competences in health promotion in the environmental education practices of community health agents
}

\author{
Competências em promoção da saúde nas práticas de educação \\ ambiental de agentes comunitários de saúde \\ Competencias en la promoción de la salud en las prácticas de \\ educación ambiental de los agentes de salud comunitários
}

\begin{abstract}
How to cite this article: Santana KFS, Machado LDS, Machado MFAS, Dias MSA, Silva LMS, Lopes MSV. Competences in health promotion in the environmental education practices of community health agents. Rev Gaúcha Enferm. 2021;42:e20200053. doi: https://doi.org/10.1590/19831447.2021.20200053
\end{abstract}

aniversidade Estadual do Ceará (UECE), Programa de Pós-Graduaçăa Cuidados Clínicos em Enfermagem e Saúde. Fortaleza, Ceará, Brasil.

- Universidade Regional do Cariri (URCA), Unidade Descentralizada de Iguatu, Departamento de Enfermagem. Iguatu, Ceará, Brasil.

Fundação Osvaldo Cruz Ceará (FIOCRUZ), Programas de Pós-graduacăo em Saúde da Família - RENASF PROFSAUDE. Fortaleza, Ceará, Brasil.

¿ Universidade Estadual Vale do Acaraú (UVA), Centro de ciências da Saúde. Sobral, Ceará, Brasil.

e Universidade Regional do Cariri (URCA), Programa de Pós-graduação em Enfermagem. Crato, Ceará, Brasil.

\section{Kelly Fernanda Silva Santana ${ }^{a}$ Lucas Dias Soares Machado ${ }^{a, b}$ Maria de Fátima Antero Sousa Machadoc Maria do Socorro de Araújo Dias ${ }^{d}$ Lucilane Maria Sales da Silva ${ }^{a}$ Maria do Socorro Vieira Lopes ${ }^{\mathrm{e}}$}

\section{ABSTRACT}

Objective: To recognize the domains of competencies in promoting health in the environmental education practices performed by community health agents.

Method: A mixed study, which adopted the Developing Competencies and Professional Standards for Health Promotion Capacity Building in Europe (CompHP) as a theoretical framework, conducted in Crato, Ceará, with 16 community health agents, based on semi-structured interviews and data organization through the ALCESTE software.

Results: The following domains of competencies in health promotion were evidenced: partnership, possibility of changes, and diagnosis. We recognize evidence signaling other domains, although with less statistical significance, such as: communication, planning and implementation, with a view to developing environmental education activities.

Final considerations: There is a mobilization of a limited number of health promotion competences in the environmental education practices developed by community health agents, which requires the wholeness of these elements to implement health promotion practices and, thus, positive transformations on the environment and health.

Keywords: Health promotion. Community health agents. Environmental health. Primary Health Care. Environment.

RESUMO

Objetivo: Reconhecer domínios de competências em promoção da saúde nas práticas de educação ambiental realizadas pelos agentes comunitários de saúde.

Método: Estudo misto, que adotou como referencial teórico o Developing Competencies and Profissional Standards for Health Promotion Capacity Building in Europe (CompHP), realizado em Crato, Ceará, junto a 16 agentes comunitários de saúde, a partir de entrevista semiestruturada e organização dos dados através do software ALCESTE.

Resultados: Foram evidenciados os domínios de competências em promoção da saúde de parceria, possibilidade de mudanças e diagnóstico. Reconhecem-se evidências que apontam outros domínios, embora com menor significância estatística, tais como: comunicação, planejamento e implementação, para o desenvolvimento das atividades de educação ambiental.

Considerações finais: Há a mobilização de um número limitado de domínios de competências em promoção da saúde nas práticas de educação ambiental desenvolvidas pelos agentes comunitários de saúde, sendo necessária a totalidade destes para concretizar as práticas de promoção da saúde.

Palavras-chave: Promoção da saúde. Agentes comunitários de saúde. Saúde ambiental. Atenção Primária à Saúde. Meio ambiente.

\section{RESUMEN}

Objetivo: Reconocer los dominios de competencias en promoción de la salud en las prácticas de educación ambiental llevadas a cabo por agentes comunitarios de salud.

Método: Un estudio mixto, que adoptó el Developing Competencies and Profissional Standards for Health Promotion Capacity Building in Europe (CompHP) como referencia teórica, realizado en Crato, Ceará, con 16 agentes de salud comunitarios, basado en entrevistas semiestructuradas y organización de datos utilizando el software ALCESTE.

Resultados: Se destacaron los siguientes dominios de competencias en la promoción de la salud: asociación, posibilidad de cambios y diagnóstico. Se reconoce evidencia que apunta a otros dominios, aunque con menos significancia estadística, tales como: comunicación, planificación e implementación, para el desarrollo de actividades de educación ambiental.

Consideraciones finales: Se registra una movilización de una cantidad limitada de competencias de promoción de la salud en las prácticas de educación ambiental desarrolladas por agentes de salud comunitarios, todo lo cual es necesario para implementar prácticas de promoción de la salud y, por lo tanto, transformaciones positivas sobre el medio ambiente y la salud.

Palabras clave: Promoción de la salud. Agentes comunitarios de salud. Salud ambiental. Atención Primaria de Salud. Ambiente. 


\section{口INTRODUCTION}

Contemporary times have witnessed an environmental crisis that threatens the life of the planet and which has been the focus of public debates around the world, strongly conveyed by the media, which explore and propagate knowledge about the ecological risks to which communities are exposed. However, the dissemination of this information has not demonstrated effectiveness in transforming the population's practices and behaviors, since aggressions to the environment are increasingly frequent and, consequently, also the increase in the risk of illness and the decrease in the quality of life of societies ${ }^{(1)}$.

In its broad sense, the environment is not restricted to economic specificities, it involves a complex system that includes interactions between its various elements, including human beings. Thus, it should not be understood only as a means from which society extracts resources to survive or to boost its economy, but as a way of life and on whose integrality depends the maintenance of ecological functions essential to life ${ }^{(1)}$.

Considering their insertion in the environmental context, it is essential that human beings appropriate their role in this plan and assume responsibilities towards the environment, expanding the understanding of environmental health beyond the related problems. It is necessary to understand the determinants of the problem and overcoming strategies, relying, for example, on environmental education to better analyze the situation and promote community participation ${ }^{(2)}$.

The current patterns of urbanization and development of companies and industries uncoordinated with the public health policies contribute to the existence of problems related to water, waste and sewage treatment, disposal of solid waste, water supply, and essential basic sanitation. The spread of diseases related a priori is added to the inadequate environmental sanitation and to the population's unpreparedness or carelessness with the environment in which they live, such as diarrhea, worms, arboviruses, and neglected tropical diseases ${ }^{(3)}$.

Environmental education materializes, then, as a strategic tool for a socio-environmental approach, seeking alternatives to solve the problems experienced by the community, both organic, as well as social and environmental(4). It must be developed through an integral view that admits the human being as a rational, sensitive and spiritual being, contemplating the work with the social determinants of health, under a multi-professional and interdisciplinary perspective. Thus, environmental education must be based on the performance of education and health professionals and on the identification of socio-environmental factors that interfere with human health and the ability to develop integrated actions. The importance of intervening with the identified demands from a participative, protagonist and shared perspective is emphasized, centered on cooperation between the actors ${ }^{(4)}$.

Within the scope of health practices, the Family Health Strategy (FHS) emerges as an important opportunity in the inclusion of users in health promotion practices, in facing social determinants and in the prevention, protection and maintenance of public health, in which environmental health is included.

In this perspective, the performance of the Community Health Agent (CHA) stands out, a professional who plays a connecting role between the FHS and the community, through activities to recognize the problems and probable solutions for the users, acting more close to the realities and their problems ${ }^{(4)}$. The contributions of the Agents to Combat Endemic Diseases (ACEDs) in environmental education practices are also highlighted, as yet another important workforce in the FHS in the field of environmental health.

Therefore, together with the ACEDs, the CHA is a relevant figure in environmental education, strengthening health promotion practices in the community and developing actions such as mapping risk areas, home visits and meetings with specific groups of the population and sectors from the community ${ }^{(5)}$.

While the CHA has the potential to develop actions to promote environmental health, the need for improving the abilities of these professionals is recognized, so that they do not limit their attention, in this context, to the association of environmental health with the idea of sanitation and control of seasonal diseases, punctually addressing the theme in times of outbreaks and epidemics, essentially reflecting a vision ${ }^{(6)}$.

Under these aspects, there is an imminent need for qualification and training of these health professionals, so that they can be multipliers of new practices that surpass the hegemonic, biomedical and assistance model, tracing new paths for the promotion of health and the empowerment of the population. Therefore, it is necessary to adopt resources, such as theoretical guiding references, that can direct and operationalize health promotion practices through competencies.

Thus, health professionals must have the skills to respond to the health needs and demands of the population, being able to articulate the knowledge acquired in the initial training, often fragmented and disjointed, with the complexity of the determinants that interrelate in life and in health care ${ }^{(7)}$.

Several countries and organizations have been engaged in the development of competencies for health promotion, 
highlighting the project entitled Developing Competencies and Professional Standards for Health Promotion Capacity Building in Europe (CompHP), of the International Union for the Promotion of Health and Education, created from other consensus on competences in health promotion and built from the contribution of researchers from various continents, among them Latin America. CompHP began to be developed in 2009, with the objective of establishing methods for implementing standards in health promotion, aiming at innovation and improvement of practices ${ }^{(8)}$.

CompHP groups a set of skills necessary to develop effective actions in health promotion, organized in nine domains, namely: favoring changes, health advocacy, partnership, communication, leadership, diagnosis, planning, implementation, and evaluation and research ${ }^{(7)}$.

In this light, it was asked: What domains of competencies in health promotion are mobilized in the environmental education activities carried out by the CHAs?

In order to answer this question and contribute to the debate around the theme, the study aimed to recognize the domains of competencies in health promotion in the environmental education practices carried out by community health agents.

\section{$\square$ METHOD}

A mixed study with a concurrent triangulation strategy, which adopted Developing Competencies and Profissional Standards for Health Promotion Capacity Building in Europe (CompHP) as its theoretical framework, a document that consolidates a set of 47 essential competencies in promoting health in nine domains ${ }^{(8)}$.

This framework establishes an international consensus of competencies in which methods are established to implement standards in health promotion, aiming at innovation and best practices in health, and can be used in the training of health promoters, as well as criteria for evaluating qualification in promotion health or evaluation of practical experiences at the undergraduate, graduate and continuing and permanent education levels $s^{(8)}$.

The study scenario comprises the FHS of a municipality in Ceará, northeastern Brazil, which has primary care coverage for the entire population, based on the work of 40 teams.

The population of interest includes professionals who work as community health agents. Of the totality of community health agents in the municipality, those who carried out environmental education activities were selected through intentional non-probabilistic sampling. To this end, prior contact was made with the municipal coordination that indicated the participants based on the activity records produced by the $\mathrm{CHA}$ professionals.

The initial contact was made by telephone, through which a face-to-face meeting was scheduled, according to the participants' availability, in a reserved place of the health unit to which they were linked. The eligibility criteria were defined as follows: being a community health agent in full activity during the study, having at least six months of experience in the position, and developing environmental education activities with the community. This study did not include those who, although indicated by other professionals in the snowball technique, did not establish contact with the researcher through the initial call or were not available for face-to-face data collection. Three attempts were made to communicate via telephone calls on different days to try to establish contact with the professionals. The professionals who were away from their activities for any reason, such as maternity leave, medical leave or strike situation, represented losses for the study. Thus, 16 community health agents who met the aforementioned criteria and accepted to contribute participated in the study.

For data collection, semi-structured interviews were used, carried out by the researchers in a private environment, with the aid of a digital recorder and a script with the guiding questions, such as: tell me about the educational practices that involve environmental issues in your area. The interviews, conducted between June and December 2018, had a mean duration of 30 minutes.

The material from the interviews was typed in full in the Microsoft Word ${ }^{\circ}$ program, constituting the corpus of the study, and saved in RichText format, constituting the preparation for the processing of lexical analysis by the ALCESTE (Anályse Lexicale by Contexte d'um Este de Segments de Texte) software, 2015 version. The corpus was entitled'agentes_de_saúde' ('health_agents'). The software processed the corpus with $87 \%$ utilization and divided it into Initial Units of Context (IUCs). In a standard analysis, after the program recognizes the indications of the IUCs, it divides the material into units of elementary context (UECs), units with a smaller fragment of meaning that will be grouped into classes, according to their similarity.

The most relevant operations in the data processing by the software were the Descending Hierarchical Classification, which shows in a dendrogram how the classes were formed and how much of thecorpus each one groups; the description of the classes, with the radicals with the highest $\mathrm{q}^{2}$; and the selection of representative UECs for each class.

The interpretation of the results through content was chosen, supported by the theoretical framework of CompHP, 
extracting from each class the UECs with a significant $q^{2}\left(q^{2} \geq 4\right)$ that referred to domains of competencies in health promotion. The concomitant triangulation strategy was due to the recognition by the software of the word function in the text and its quantification and understanding of class delimitation, which are defined according to the occurrence of the words and their textual function.

The study respected the rules of research involving human beings, according to Resolution No. 466/2012 of the Brazilian National Health Council and appreciation and approval by the Research Ethics Committee of the Regional University of Cariri, under opinion No. 103/2011. All the participants signed the Free and Informed Consent Form, and had their identity preserved through the CHA code for each professional, followed by the number corresponding to the order of the interviews.

\section{RESULTS}

The study included the discourse of 16 community health agents, all of whom were female, with a minimum age of 33 years old and a maximum age of 60 years old. Most of the professionals had completed high school (56.25\%), followed by professionals with higher education (43.75\%). As for the time working with the FHS, most of them have worked for ten years or more (62.5\%).
The processing of data by the software identified 2,464 distinct forms, grouped into 475 UECs, which were classified into three classes, as illustrated in Figure 01. Each class is structured by UEC groupings with homogeneous vocabulary and words meaningful to the analyzed context.

\section{Class 1 - Environmental education in the territory}

This class originated from the association of 227 UECs and 108 analyzable words, representing the greatest statistical significance in the context of the study in terms of UEC aggregation, making up 55\% of the corpus. It expresses the participants' knowledge and the way they develop their environmental education practices, mainly addressing discussions about garbage $\left(q^{2} 84\right)$, wasteland $\left(q^{2} 12\right)$, fires $\left(q^{2} 9\right)$ and cleaning $\left(q^{2} 11\right)$. It is revealed that the environmental education practices have a seasonal character, evidenced by the frequency of the terms dengue $\left(q^{2} 24\right)$, mosquito $\left(q^{2} 9\right)$ and disease $\left(q^{2} 14\right)$, associated with the execution of these in the moments of arbovirus outbrea$\mathrm{ks}$ in the territory. In addition to these, the student $\left(q^{2} 7\right)$, school ( $\left.q^{2} 13\right)$ and child $\left(q^{2} 18\right)$ elements deserve to be highlighted, signaled as partners of the health promotion practices in the community.

\begin{tabular}{|c|c|c|c|c|c|}
\hline \multicolumn{2}{|c|}{ Class 1} & \multicolumn{2}{|c|}{ Class 2} & \multicolumn{2}{|c|}{ Class 3} \\
\hline Word & $\mathbf{q}^{2}$ & Word & $q^{2}$ & Word & $q^{2}$ \\
\hline Garbage & 84 & Develop & 22 & Management & 91 \\
\hline Dengue & 24 & Nurse & 21 & Weak & 83 \\
\hline Child & 18 & Physician & 16 & Support & 76 \\
\hline Disease & 14 & Agents & 16 & Partnership & 67 \\
\hline School & 13 & Happen & 11 & Secretariat & 56 \\
\hline Land & 12 & Technician & 12 & Municipality & 50 \\
\hline Cleaning & 11 & NASF & 10 & Alone & 12 \\
\hline Burned & 9 & Demand & 10 & Encourage & 12 \\
\hline Mosquito & 9 & Service & 8 & Difficulty & 12 \\
\hline Student & 7 & Meeting & 8 & Team & 11 \\
\hline
\end{tabular}

Figure 1 - Dendrogram of descending hierarchical classification Source: Research data, 2020. 
With regard to the domains of competencies in health promotion, the domains of partnership and possibility of changes were manifested in this class, as shown in Chart 1.

The partnership domain is manifested in the reports of the CHAs considering a joint action with individuals from the community, such as children, and strategic sectors, like education. The possibility of changes domain is revealed in the purpose of the actions developed by the professionals with regard to health promotion, presenting itself as a possibility of working with specific groups, such as the child population, aiming at transformations in reality.

\section{Class 2 - Interdisciplinary action for environmental education}

The second class with the highest statistical and semantic significance is made up of 139 UECs and 83 analyzable words, representing 33\% of the corpus analyzed. This class evidenced the fragility of the interdisciplinary work of the FHS team in conducting environmental education actions, which included the nurse $\left(q^{2} 21\right)$, the physician $\left(q^{2} 16\right)$, the nursing technician ( $\left.q^{2} 12\right)$, community health agents $\left(q^{2} 16\right)$, and the professionals who make up the team of the Center for Extended Family Health and Primary Care (Núcleo de Ampliado em Saúde da Familia e Atenção Básica, NASF-AB) (q² 10), including: social worker, physical educator, physiotherapist, speech therapist, nutritionist, and psychologist. There is also the recognition that performance needs to be guided by the needs of the realities of the attached territory, considering the knowledge of the individuals and their culture, in order to act effectively on the determinants of health in the location.

The participants'statements demonstrate the presence of the partnership and diagnosis domains, exemplified in Chart 2.

\begin{tabular}{c|l|}
$\begin{array}{c}\text { Domain of } \\
\text { competences }\end{array}$ & \multicolumn{1}{c|}{ Illustrative UEC } \\
\hline Partnership & $\begin{array}{l}\text { The best to work with are the children, the great ally of the health agent in this issue of transformation, } \\
\left.\text { zeal, care for the environment. (UEC No.172, } \mathrm{q}^{2} 8\right) \\
\text { We invite several sectors, social action, Hemoce, representative of education. We invited education } \\
\left.\text { because we wanted them to pass on to teachers and directors. (UEC No.290, } \mathrm{q}^{2} 7\right)\end{array}$ \\
\hline $\begin{array}{c}\text { Possibility } \\
\text { of changes }\end{array}$ & $\begin{array}{l}\text { They both do (the children) and they tell the parents, they correct the parents when they do wrong. } \\
\left(\mathrm{UEC} \text { No.173, } \mathrm{q}^{2} 8\right)\end{array}$ \\
\hline
\end{tabular}

Chart 1 - Domains of competences evidenced in Class 1. Crato, 2020

Source: Research data, 2020.

\begin{tabular}{|c|c|}
\hline $\begin{array}{l}\text { Domain of } \\
\text { competences }\end{array}$ & Illustrative UEC \\
\hline Partnership & $\begin{array}{l}\text { The whole team has its difficulties, but thanks God when it comes to developing these educational } \\
\text { activities, the nurse always participates, the one who is more difficult to go is the doctor. (UEC No.115, } \\
\left.q^{2} 15\right) \\
\text { When there is some activity, we invite the NASF staff, they always help, but it is because they are in } \\
\left.\text { several teams that it is difficult to have this bond with the people. (UEC No.56, } \mathrm{q}^{2} 22\right)\end{array}$ \\
\hline Diagnosis & $\begin{array}{l}\text { Each location has its own way of being, so the ways of working have to be different. [...] I have my way } \\
\left.\text { of working because I know the people, even the way they talk. (UEC No.18, } \mathrm{q}^{2} 27\right) \\
\text { I go to the houses when I'm doing the routine visit, so I see the focus of what I want, and identify the } \\
\text { need for us to work. (UEC No.64, } \mathrm{q}^{2} 9 \text { ) }\end{array}$ \\
\hline
\end{tabular}

Chart 2 - Domains of competences evidenced in Class 2. Crato, 2020

Source: Research data, 2020. 
The partnership domain, expressed in a new class, is related to the need for the involvement of the CHAs with other professionals, through teamwork, to achieve success in their practices, with some professionals, such as nurses and the NASF, more available at these times. The diagnosis domain, on the other hand, relates to the strategies adopted to recognize the reality and health needs of the population under their health responsibility, often linked to subjectivity and qualitative verification, made possible, mainly by the close relationship of the $\mathrm{CHA}$ with the community and the bond arising from this contact.

\section{Class 3 - Inter-sectoral articulation for environmental education}

Essentially, it is the need to implement inter-sectorality for the proper performance of the environmental education and health promotion practices, not recognizing in the studied context appreciation and management support for this achievement. This aspect is evidenced in the use of the terms management $\left(q^{2} 91\right)$, weak $\left(q^{2} 83\right)$, support $\left(q^{2} 76\right)$, partnership $\left(q^{2} 67\right)$, secretariat $\left(q^{2} 56\right)$ and municipality $\left(q^{2} 50\right)$, and their articulation in the participants'speeches. The structure of this class involves 139 UECs and 83 analyzable words, corresponding to the statistical significance of $12 \%$ of the corpus.

Chart 3 illustrates the presence of the partnership and possibility of changes domains, recognized in the UECS present in this class, and the participants'speeches corresponding to these domains.

The partnership domain herein shown differs from that presented in the previous classes in that it focuses mainly on inter-sectoral collaboration with other spheres, in order to understand this relationship as a powerful strategy for coping with the health problems related to the social determinants, even though it is established in a punctual way in the context under study. As the partnership domain develops, progress in the possibility of changes domain is perceived, characterized by the empowerment of the individuals in the environmental education actions, strengthening access to information and autonomy for decision-making.

In summary, the following domains of competences in health promotion of the CompHP were evidenced: partnership, possibility of changes, and diagnosis. Evidence is recognized that points to other domains, such as: communication, planning and implementation, for the development of environmental education activities. However, they do not present themselves in an expressive way in the practices reported by these professionals, not presenting, in this study, statistical significance that allows asserting their mobilization.

\section{DISCUSSION}

The work in environmental education and health promotion is based on the recognition of the environment as a set of conditions for the social reproduction of life, where several factors have a direct or indirect influence on the ways of living, being healthy, getting sick, and taking care of populations, such as inclusive education, job and income availability, basic sanitation, and leisure spaces ${ }^{(1)}$.

Thus, it is imperative that the environmental education actions developed by the FHS professionals, including the $\mathrm{CHAs}$, abandon the seasonal character, being present in any and all opportunities for contact with the community to address the social determinants of health and structuring and monitoring therapeutic projects. In addition to knowledge about the environment and its sustainable preservation, personal values and beliefs and their direct relationship with the environment in which the individuals and their

\begin{tabular}{|c|l|}
$\begin{array}{c}\text { Domain of } \\
\text { competences }\end{array}$ & \multicolumn{1}{c|}{ Illustrative UEC } \\
\hline Partnership & $\begin{array}{l}\text { All the departments should be more aware that we should work in partnership, because if we } \\
\text { worked in partnership, then everything would work out. Now alone we have no strength. (UEC } \\
\left.\text { No.236, } \mathrm{q}^{2} 31\right) \\
\text { We set up an action, the post team, the residents' association and the school, which is next to } \\
\text { the association. Then it worked because all the sectors were working together. (UEC No.193, } \\
\left.\mathrm{q}^{2} 15\right)\end{array}$ \\
\hline Possibility of changes & $\begin{array}{l}\text { I work like this: I show him, I guide him how it has to be done, because if they learn they start } \\
\left.\text { taking care of their house and of the neighbor's house. (UEC No.84, } \mathrm{q}^{2} 27\right)\end{array}$ \\
\hline
\end{tabular}

Chart 3 - Domains of competences evidenced in Class 3. Crato, 2020 Source: Research data, 2020. 
families live and relate must also be considered, so that they are involved in these practices and considered actors responsible for this process ${ }^{(9)}$.

In addition to ensuring the inclusion of the community, it is essential that the FHS professionals articulate with each other and with relevant related sectors to act on the determinants of health, allowing for a broad view of the health-disease-care process, ensuring commitment to the transdisciplinary work and development of innovative education practices that abandon the routine and prescriptive character and are capable of promoting autonomy, decision-making and social empowerment ${ }^{(10)}$.

The recognition of these aspects and the ability to make them operational are desirable products for professional training and qualification. In this context, competence training, a current trend in the field of education, has proved to be efficient in promoting knowledge, skills and attitudes consistent with professional and service integration, coordination and teamwork, as well as acting on the real needs of the territories ${ }^{(11)}$.

Specifically in terms of health promotion activities, the development of skills in this field is associated with the training of professionals capable of articulating and putting into practice, in a dynamic and complex way, the theoretical and methodological principles of health promotion, considering reflections about contexts, their coping challenges and the expectations of the population ${ }^{(12)}$.

The CompHP framework of competences in health promotion groups a set of nine domains of essential competencies capable of strengthening the public health workforce, being fundamental for the effective provision of health actions ${ }^{(13)}$. Of these domains, three were manifested in the environmental education practices described by the Community Health Agents: partnership, possibility of changes, and diagnosis. The partnership domain refers to collaboration among disciplines, actors and sectors, to increase the reach and impact of the health promotion actions, in addition to ensuring their sustainability ${ }^{(8)}$. It then comprises teamwork and inter-sectoral work.

Teamwork with a focus on health promotion and environmental education is developed collaboratively, expanding the actors participating in the process and comprising, in addition to the minimum FHS team, professionals from the NASF-AB, education, social assistance, and public security, among others. Then, the scope of action that makes professionals responsible for comprehensive and holistic care is expanded ${ }^{(14)}$.

Thus, working in a team goes beyond the simple interaction with other professionals and establishing a flow of reference and counter-reference, reaching dialog between these professionals, adoption of joint decisions, sharing of responsibilities, development of negotiations, favoring comprehensiveness and reducing fragmentation of care ${ }^{(14)}$.

Working with other actors also includes involving other sectors, ensuring longitudinality and circularity of care and respect for the complexity of the health reality, recognizing that the desired results come from shared and contextualized actions, in which knowledge, commitments, values, affections, responsibilities and actions are shared. Thus, inter-sectoral performance in environmental health comprises the professional practice that considers the complexity of doing health and the production of care, defending a collective view and accountability with the territory ${ }^{(15)}$.

Dealing with partnerships, then, requires the ability to engage with various sectors with the potential to contribute to health promotion actions; facilitating work with partners based on valuesand principles of health promotion; as well as the construction of collaborative work and mediation of the objectives and interests of the sectors, ensuring the development and sustainability of the processes ${ }^{(8)}$.

In turn, the possibility of changes domain is related to strengthening the action capacity of individuals, groups and the community, in promoting health, idealizing improvements for health and quality of life, as well as reducing social inequities ${ }^{(8)}$.

It consists, therefore, in the development of autonomy and empowerment of the individuals so that they are able to decide for the best for their health, their life, and the environment in which they are inserted. It is a matter of collectively mobilizing forces capable of generating transformations and driving movements in the face of the inertia of the services and territories ${ }^{(16)}$.

Developing autonomy and empowering, in the educational work developed by the CHAs, refers to enabling individuals to act in the face of their own problems and needs, mobilizing their resources and promoting healthier actions in their lives ${ }^{(16)}$.

The health promoter, in this domain, must be able to collaborate with other sectors to promote the development of policies with positive impacts on health; use approaches that provide empowerment, participation, leadership and equality; facilitate the development of personal skills for maintaining and improving health; and collaborate with social actors to redirect the health services, promoting health and reducing inequalities ${ }^{(8)}$.

In this context, the domains of partnership and possibility of changes are connected from the defense of integration between the actors and services to work on the problems of the territory, assuming increasing responsibilities, providing care and, thus, transforming it ${ }^{(17)}$. 
On the other hand, the diagnosis domain considers the needs assessment in a context of political, economic, social, cultural, environmental, behavioral and biological determinants, and the resources presented in it, which promote or compromise health ${ }^{(8)}$.

It demonstrates its relevance in meeting the health needs that lead to improvements in care, well-being and ways of life, providing changes in the current biomedical model when considering social aspects of care, such as interests, experiences, ideas, valuesand autonomies ${ }^{(18)}$.

In this sense, the use of subjective and qualitative approaches by the CHAs to approach the demands of their territories of operation considers inter-subjective and political conditions, in addition to the biological, material and concrete, considering man and his environment in its complexity ${ }^{(18)}$.

Considering subjectivity shows advances in overcoming the biomedical model of conducting health actions. However, both aspects must be considered in the integrality of health care, therefore it is recommended that the professionals use diagnostic methods that make it possible to identify health needs, social equipment, based on epidemiology and the potential and challenges of the territory, in addition to to diagnosing health, environmental and social risks ${ }^{(14)}$.

Therefore, it is necessary to involve the population and guarantee social participation in the performance of a systematized work of appropriation and analysis of realities, so as to support the health promotion and environmental education practices.

Thus, the educational practices in favor of building sustainable environments must be based on a conception of reflective and engaged education, in which knowledge and practices are built with the learning and teaching subjects. Thus, such actions must be associated with critical thinking and with emancipatory practices, with a focus on changing the behavior and attitudes of those involved, fostering social empowerment and the preparation to make healthy decisions regarding their autonomy, as expressed in the assumptions of health promotion ${ }^{(19)}$.

It is noteworthy that only three out of nine domains of competencies in health promotion were manifested in the participants'speeches, with statistical strength through the processing of the software, which points to the need to develop the other domains - communication, health advocacy, leadership, planning, implementation and evaluation, and research - in addition to the improvement of those presented. These domains need to be improved and strengthened in the development of environmental education activities, contemplating the intercommunication of all the domains proposed by CompHP.
Besides, even the domains evidenced in the CHAs'speeches are presented in a restricted manner when thinking about the broad concept and the principles of health promotion; it is necessary that they act beyond the specific field of action of the professional category and meet the socio-environmental perspective of health promotion.

The correlation between the domains formulated by CompHP demonstrates the relevance of the joint development of all, since they are connected and are fundamental to the effectiveness of the health promotion practices. As an example of this correlation, we can point out the relation of the advocacy, leadership and partnership domains and the relation of the diagnosis, planning, implementation and evaluation, and research domains.

Carrying out health promotion actions in partnership with other actors and services encourages leadership and demands for improvements, acquiescing to greater dissemination of proposals, with a positive impact on the territories, on people's lives, and on the activities of the health services. Thus, the advocacy, leadership and partnership domains are mobilized, mainly through health education and health advocacy movements ${ }^{(20)}$.

The diagnosis, planning, implementation, and evaluation and research domains are articulated in a continuous, procedural and interdependent manner, in which practices must be based on a contextual and situational diagnosis, preceding the programming and planning of actions that will be implemented and constantly evaluated, in accordance with the scientific literature, popular knowledge, health needs of the population, and experience of the professionals involved ${ }^{(21)}$.

Thus, the need to support the training of health professionals in health promotion and the development of skills emerges, corroborating the development of professional standards, quality systems, professional preparation with ethics and efficiency and contributing to establish health promotion as a specialized and powerful field of practices.

In the context of the FHS and considering the performance of thousands of CHAs in the country, training processes focused on the professionals and their reality, such as permanent education proposals, can be valuable. It is then possible for them to learn by doing continuously and in their daily lives, favoring learning, the bond with the population, development of autonomy, and a critical view of the work process, about the health-disease-care process, and about caring for the environment ${ }^{(20)}$.

In view of this panorama, it is inferred that the development of competencies in health promotion is valuable for the implementation of health promotion practices and 
more effective environmental education, with quality, ethics and adequate to the complex and heterogeneous realities and experiences found in primary care. Thus, it is argued that the CHAs are recognized for their powerful role in the community and that their training needs are met to improve their activities, both in environmental education and in other aspects of health promotion.

\section{FINAL CONSIDERATIONS}

The statements of the CHAs revealed the mobilization of the following domains of competences in health promotion of CompHP: partnership, possibility of changes, and diagnosis in the environmental education practices developed in the context of primary care. It is recognized that the knowledge, skills and attitudes that support these domains contribute to effective and ethical actions for health promotion, performed based on the needs of the territory and on the complex realities that it presents, establishing links with other actors and scenarios and, thus, collaborating for the realization of positive transformations for health and for quality living.

Although only three domains have been manifested, the importance of the others in the environmental education practices of the CHAs is emphasized, and they must be developed in a joint and correlated manner, in order to guarantee effective actions in the context of primary care. The development of competencies in health promotion manifests itself as a powerful alternative in overcoming this challenge, which may go through the initial training and permanent education of the health professionals.

The CompHP framework shows relevance to guide training processes whose objective is to train professionals with competencies in health promotion, given its formulation from a broad perspective of domains, recognized as essential in several countries around the world. It is inferred that this is an adequate reference to guide CHA training processes in offering personal resources to promote health and environmental education.

Finally, it is pointed out that the recognition of the domains of competencies in health promotion results from a subjective look at the participants' speeches, which can materialize as a limitation of the study. However, the use of software and the adoption of the theoretical framework were strategies adopted to overcome this limitation, based on concrete references and statistical analysis in this recognition. Therefore, the relevance of developing other studies on the theme is pointed out, in order to identify, for example, why these domains stood out from the others and what has contributed to their mobilization.
This study contributes to the health field by confirming the relevance of the development of competencies in health promotion for the performance of effective practices, with quality, appropriate to reality and based on ethics and, thus, with the potential to establish health promotion as a paradigm involved with social well-being, with quality of life and empowerment of the population.

\section{REFERENCES}

1. SariV, Camponogara S. Environmental perceptions in the vision of environmental educators of a hospital institution. Rev Contexto Saúde. 2017;17(33):200-14. doi: https://doi.org/10.21527/2176-7114.2017.33.200-214

2. Peres RR, Camponogara S, Costa VZ, Terra MG, Nietsche EA. Health and environment: (in) visibilities and (dis) continuation in nursing professional training. Esc Anna Nery. 2016;20(1):25-32. doi: https://doi. org/10.5935/1414-8145.20160004

3. Guimarães M, Granier NB. Educação ambiental e os processos formativos em tempos de crise. Rev Diálogo Educ. 2017;17(55):1574-97. doi: https://doi. org/10.7213/1981-416X.17.055.DS06

4. Simas PRP, Pinto ICM. Health work: portrait of community workers in the Northeast region of Brazil. Ciênc Saúde Coletiva. 2017;22(6):1865-76. doi: https://doi.org/10.1590/1413-81232017226.01532017

5. Rabelo AOM, Bueno DS, Andrade HS. Análise do trabalho do agente comunitário de saúde na Estratégia de Saúde da Família. Rev Pesq Saúde. 2018 [cited 2020 Jan 5];19(1):33-7. Available from: http://www.periodicoseletronicos.ufma.br/ index.php/revistahuufma/article/view/9178

6. Camponogara S, Erthal G, Viero CM. The environmental problem in the view of community health agents. Cienc Cuid Saude. 2013;12(2):233-40. doi: https:// doi.org/10.4025/cienccuidsaude.v12i2.18584

7. Pinheiro DGM, ScabarTG, Maeda ST, Fracolli LA, Pelicioni MCF, Chiesa AM. Health promotion competencies: challenges of formation. Saúde Soc. 2015;24(1):1808. doi: https://doi.org/10.1590/S0104-12902015000100014

8. Battel-Kirk B, Barry MM, Zanden G, Contu P, Gallardo C, Martinéz A, et al. Operationalising and piloting the IUHPE european accreditation system for health promotion. Glob Health Promot. 2014;22(3)25-34. doi: https://doi. org/10.1177/1757975914545386

9. Castro AS, Madeira NG. Educação em saúde na escola: uma experiência quantitativa no ensino de verminose para alunos do ensino fundamental. 2013. II Congresso Online de Gestão, Educação e Promoção da Saúde; 2013 out 24-26, Rio de Janeiro, Brasil.

10. Souza FPP, Machado LDS, Santana KFS, Rocha RMGS, Lopes MSVL, Machado MFAS. Health promotion in multidisciplinar residency: contributions to the training process. J Nurs Educ Pract. 2017;7(6):80-9. doi: https://doi. org/10.5430/jnep.v7n6p80

11. Fragelli TBO, Shimizu HE. Prospecções para desenvolvimento de políticas públicas de formação de profissionais de saúde a partir da análise do cenário brasileiro de competências. Rev Bras Enferm. 2013;16(2):667-74. doi: https:// doi.org/10.1590/S0103-73312013000100011

12. Tavares MFL, Rocha RM, Bittar CML, Petersen CB, Andrade M. Health promotion in professional education: challenges in Health and the need to achieve in other sectors. Ciênc Saúde Coletiva. 2016;21(6):1799-808. doi: https://doi. org/10.1590/1413-81232015216.07622016 
13. Mereu A, Sotgiu A, Buja A, Casuccio A, Cecconi R, Fabiani L, et al. Professional competencies in health promotion and public health: what is common and what is specific? review of the European debate and perspectives for professional development. Epidemiol Prev. 2015 [cited 2020 Jan 3];39(4 Suppl 1):33-8. Available from: http://www.epiprev.it/materiali/2015/EP2015_14S1_033.pdf

14. Oliveira TB, Shimizu HE. Competências profissionais para o trabalho do Núcleo de Apoio à Saúde da Família. Rev APS. 2014;17(3):334-44. doi: https://doi. org/10.1590/1981-52712015v40n2e02702014

15. Dias MAS, Parente JRF, Vasconcelos MI0, Dias FAC. Intersetorialidade e estratégia Saúde da Família: tudo ou quase nada a ver? Ciênc Saúde Coletiva. 2014;19(11):4371-82. doi: https://doi. org/10.1590/1413-812320141911.11442014

16. Brehmer LCF, Ramos FGS. Experiências de integração ensino-serviço no processo de formação profissional em saúde: revisão integrativa. Rev Eletr Enf. 2014;16(1):228-37. doi: https://doi.org/10.5216/ree.v16i1.20132

17. Vendruscolo C, Prado ML, Kleba ME. Teaching-service integration within the National Professional Health Education Reorientation Program. Ciênc Saúde Coletiva. 2016;21(9):2949-60. doi: https://doi. org/10.1590/1413-81232015219.12742015

\section{- Corresponding author:}

Lucas Dias Soares Machado

E-mail: lucasdsmachado@hotmail.com
18. Silva KL, Sena RR, Belga SMMF, Silva PM, Rodrigues AT. Health promotion: challenges revealed in successful practices. Rev Saúde Pública. 2014;48(1):7685. doi: https://doi.org/10.1590/S0034-8910.2014048004596

19. Jacobi PR, Tristão M, Franco MIGCA. A função da educação ambiental nas práticas colaborativas: participação e engajamento. Cad Cedes. 2009;20(77):6379. doi: https://doi.org/10.1590/S0101-32622009000100005

20. Netto L, Silva KL, Rua MS. Competency building for health promotion and change in the care model. Texto Contexto Enferm. 2016;25(2):e2150015. doi: https://doi.org/10.1590/0104-07072016002150015

21. Evangelista SC, Sampaio JV, Machado LDS, Tamboril ACR, Moreira MRC, Viana $M C A$, et al. Course of health promotion actions on multiprofissional residency: analysis in the light of a European reference. Tempus, Actas Saúde Colet. 2016 [cited 2020 Jan 3];10(4):69-82. Available from: https://www.tempusactas. unb.br/index.php/tempus/article/view/2291

\section{Associate editor:}

Rosana Maffacciolli 